\title{
sciendo
}

\author{
KATARZYNA MEŁGIEŚ
}

\section{The legal status of physiotherapists' profession}

\begin{abstract}
Physiotherapy is a discipline of clinical medicine, using its own diagnostic and therapeutic methods, including the treatment of movement and physical stimuli. The new legal regulations resulting from the Act of 25 September 2015 on the Profession of Physiotherapy have granted a special professional status to this group of specialists, what results from the fact that it is recognized as an independent medical profession. It should be noted, however, that the introduced law, although expected for many years, did not stabilize the legal situation of this professional group until the end. There are still doubts of a juridical nature which make it difficult to provide unambiguous answers to the basic questions regarding the legal status of physiotherapists as persons performing an independent medical profession. This publication, referring to the applicable statutory regulations and views presented in the legal doctrine, analyzes the current legal status, indicates the weaknesses of the adopted legislative solutions and avoids the changes.
\end{abstract}

Keywords: physiotherapists, profession of public trust, medical profession, healthcare system, healthcare services, medical activities.

DOI: $10.2478 /$ pjph-2018-0012

\section{INTRODUCTION}

Physiotherapists, in addition to doctors and nurses, are the third professional group in the health care system [1]. The profession of physiotherapist is a young one, as it was placed on the list of professions and specialties only in 2004, and has been subjected to statutory regulation since 31 May 2016, when the provisions of the Act of 25 September 2015 on the Profession of Physiotherapy (APP) entered into force, the aim of which is a comprehensive regulation of the rules of practising this profession. Physiotherapy is a discipline of clinical medicine, which uses its own diagnostic and therapeutic methods, including movement therapy and physical stimuli therapy.
AIM
The aim of this publication is to analyze the current legal status of physiotherapists' profession in Poland and indicate the weaknesses of the adopted legislative solutions.
The manner of regulating and the scope of this legal regula- tion makes it possible to place this profession as a special one, the practise of which is subjected to particular legal require- ments. It should be pointed out that the Act does not intro- duce any legal definition of physiotherapist's profession and its specificity. Initially, this profession has been indicated in the annex to the Ordinance of the Minister of Labor and Social Policy of 7 August 2014 on the Classification of Occupations and Specializations for Labor Market Needs and the scope of its application (Dz.U.2018.227) under item 2292 (physiothera-

pists, item 229201, and physiotherapy specialists under item 229202). Nevertheless, one can find a set of features defining designata that allow to determine the legal status of this profession.

The most important feature determining the exceptional professional status of this group of entities, resulting from Article 2 of the APP, is recognizing it as an independent medical profession. The above status has been determined, according to the justification of the draft act on physiotherapist's profession, by the conditions, circumstances and relationships in which this activity is performed. It was also influenced by the fact that individuals performing such activities should be characterized by special psycho-physical and moral features, as well as should perform it in an organized manner, constantly raising their professional skills and be subjected to special professional responsibility [3].

Physiotherapists practise an independent medical profession. In essence, what does it mean that it is a medical profession? The essential features of a medical profession result from normatively distinguished components, based on the currently applicable legal acts. And so it is indicated that a medical profession can be practised by individuals who are entitled under separate provisions to provide health care services and who possess professional qualifications to provide health care services of a specific scope or in a specific field of medicine [Article 2, paragraph 1 point 2 of the Act on Therapeutic Activity (ATA)] [4].

The definition of the term "medical profession" distinguishes several elements. The doctrine of medical law emphasizes 
that the key concept here is the concept of "a health care service". Its understanding follows from the way in which it was subjected to legal regulation in various legal acts. On their grounds, it may be concluded that the Legislator clearly recognizes as medical services only professional "medical activities" (Article 2, paragraph 1, point 2 in conjunction with Article 17, paragraph 1, point 3 of the ATA), corresponding to the requirements of current medical knowledge (Article 6, paragraph 1 of the Act on Patients' Rights (APR) [5], being an intangible service with the possibility of using material items (Article 68, paragraph 2 of the Constitution [6] in connection with Article 5, point 34 of the Act on Health Care Services (AHCS)) [7], undertaken only for the purpose specified by the Legislator (Article 2, paragraph 1, point 10 of the ATA in connection with Article 8 of the APP), wherein individuals performing medical activities must be guided by the rules of professional ethics established by the relevant professional self-governments (Article 8 of the APP) [8]. The scope of health care services which physiotherapists are entitled to perform is not closed. According to Article 4, paragraph 2 of the APP, practicing the physiotherapist's profession consists in providing health care services, in particular: functional diagnostics of the patient; qualifying, planning and conducting physical therapy; qualifying, planning and conducting kinesiotherapy; qualifying, planning and conducting a massage; prescribing medical devices in accordance with the regulations issued on the basis of Article 38, paragraph 4 of the Reimbursement Act; matching medical products to the patient's needs; teaching patients how to use medical devices; conducting physio-prophylactic activity that consists in popularizing pro-health behaviors and shaping and maintaining the fitness and efficiency of people of all ages to prevent disability; issuing opinions and decisions regarding the functional status of people undergoing physiotherapy and the course of the physiotherapy process; teaching patients about compensatory mechanisms and adaptation to the changed potential of their body functions and activity. The activities that are also seen by the APP as practising this profession are: teaching physiotherapists and performing work for the improvement of professional education of physiotherapists; conducting scientific and research work in the field of physiotherapy; managing professional work of physiotherapists; employment in administrative positions where activities related to the preparation, organization or supervision of the provision of health care services are performed.

At this point it should be emphasized that the doctrine of medical law is consistent as far as complexity of the health care service process is concerned. They also admit that the concept of health care does not consume medical activities that rely strictly on treatment, but also allows non-curative activities. What is important, is that in order to determine whether a given person practises a medical profession, it is enough for them to start such work and conduct only one medical activity [10]. As D. Karkowska rightly emphasizes, medical activities inscribed in the essence of the scope of the term "medical professions" should not be limited only to the area of medicine, but must take into account the dynamic development of medical sciences and health sciences. Hence, the author concludes that the casuistic classification of activities as medical activities is primarily a task for medical sciences and health sciences [8]. On the other hand, on the grounds of law, the important premises defined by the Legislator are those that will enable objective distinction of health care services as medical activi- ties from other types of services. Medical activities are intangible services, so the patients cannot see the service before they "receive" it. Medical activities can only be undertaken for the purpose specified by the Legislator (Article 2, paragraph 1, point 10 of the ATA in connection with Article 8 of the APR). Health care services are described as medical activities "for maintaining, saving, restoring and improving health and other medical activities resulting from the treatment process or resulting from the rules governing their performance" (Article 2, paragraph 1, point 10 of the ATA). Thus, the design of health care service does not allow for the provision of services not related in any way to maintaining, saving, restoration or improvement of health [8]. The legal definition of this concept, contained in Article 5, point of the AHCS, explains the issue of a health care service in a similar way, indicating that it is "an activity for prevention, maintenance, saving, restoration or improvement of health and other medical activities resulting from the treatment process or from separate regulations governing its provision". Both definitions see medical activities not only as actions taken in the case of illness, but also activities that improve health.

The second factor affecting the legal status of the medical profession is the possession of appropriate professional qualifications. For physiotherapists these qualifications follow from the content of Article 13, paragraph 3 of the APP and they refer to both acquired knowledge and competences. It should be emphasized that physiotherapists constitute a heterogeneous professional group, having in mind different ways of acquiring qualifications, which the Legislator considers sufficient to award this professional title. Currently, competences to perform this profession result from starting and completing the appropriate educational path, which require official confirmation in the form of a diploma. A diploma confirming formal qualifications is a diploma issued to a person who:

- started a uniform 5-year higher education in physiotherapy after 1 October 2017, covering at least 300 ECTS points, including at least 160 ECTS points in the field of physiotherapy, completed a six-month professional training, obtained a Master's degree and passed a State Physiotherapy Exam - the current model educational path conforming physiotherapists' professional qualifications;

- started higher education in the field of physiotherapy after 30 September 2012 and before 1 October 2017, comprising at least 180 ECTS points, including at least 100 ECTS points in the field of physiotherapy, obtained a Bachelor's degree or, in addition, completed higher education comprising at least 120 ECTS points, including at least 60 ECTS points in the field of physiotherapy and obtained a Master's degree;

- after 31 December 1997 started university studies in the field of physiotherapy in accordance with the educational standards established in separate regulations and obtained a Bachelor's or a Master's degree in this field; before 1 January 1998 started higher studies in the field of functional rehabilitation or general rehabilitation and obtained a Master's degree in this field; started studies at the Academy of Physical Education before 1 January 1998, obtained a Master's degree and graduated in 1st or 2nd degree specialization in the field of functional rehabilitation; before 1 January 1980 started studies in physical education and obtained a Master's degree in this field, and completed a twoyear specialization in the field of therapeutic gymnastics or 
functional rehabilitation as part of the course, confirmed by a functional rehabilitation instructor's card or a therapeutic gymnastics instructor's card; before 1 January 1980 started studies in physical education, obtained a Master's degree in this field and completed a three-month specialized course in rehabilitation in accordance with the regulations of the Central Committee of Physical Culture and Sport; graduated from a public or non-public post-secondary school with the rights of a public school before the Act came into force and obtained a professional title of a Physiotherapy Technician.

In order to obtain the right to practice the profession, a person has to have his/her qualifications and professional skills, as well as psycho-physical and moral traits verified. According to Article 13, paragraph 1 of the APP, these are: full legal capacity; an appropriate state of health that allows one to practise the profession of physiotherapist, which is confirmed in particular by a relevant medical certificate; knowledge of the Polish language sufficient to practise the profession of physiotherapist; giving a guarantee of proper practise of physiotherapist's profession - in particular, such person may be convicted by final judgement for intentional crime against life and health, against sexual freedom and decency and for acts specified in Article 207 and Article 211 PK The basis for obtaining professional qualifications is the license to practice the profession, subjected to entry into the National Register of Physiotherapists and confirmed by an appropriate official document. The entry is made on the basis of resolutions on recognition or granting of the right to practice the profession by the National Council of Physiotherapists - NCP (Article 22 of the APP). The adopted regulation is contradictory and internally inconsistent. The Act uses two different terms to indicate two different activities of the NCP : a resolution on the determination of the right to practice the profession and a resolution on granting the right to practice the profession. This should be recognized as a legislative mistake, given that a differentiation of these activities has not been consistently made, in particular the regulation fails to indicate any elements of the application for recognition of entitlements, but only indicates elements of the application for granting of the right. The Act further specifies the basis for adopting a resolution regarding recognition of the right, yet there is no appropriate provision in relation to the resolution on granting of the right. Thus, none of them has been subjected to full regulation allowing for full proceedings with the indication of the legal basis for successive actions taken by the National Council of Physiotherapists.

It should be indicated that the Legislator determined the independent character of this medical profession without indicating precisely how the independence should manifest. It may be assumed that this independence should guarantee the freedom of professional activities, in accordance with the gained experience, competences and skills. This can be inferred from the content of Article 4, paragraph 1 of the APP, according to which, physiotherapists practise the profession with due diligence, in accordance with the principles of professional ethics, with respect for patient's rights, care for his safety and using the recommendations of current medical knowledge. In addition, it is emphasized that when practising the profession, physiotherapists cooperate with people practising other medical professions. It seems that to a certain extent, taking into account the specificity of health care services which physiotherapists are entitled to perform, guarantees of professional independence should correspond with the guarantee of freedom of choice of methods of conduct. This has been expressed by the Legislator, who directly grants the right contained in Article 6, paragraph 2 of the APP, according to which, in the case of reasonable doubt concerning a doctor's orders in the field of physiotherapy, the physiotherapist has the right to demand from the doctor who issued the order to justify the need to perform it, as well as the right to refuse to perform a specific service. Here, one should also emphasize the fact that professional independence should be understood as freedom in the scope of not being subjected to market mechanisms, social pressures or administrative requirements. A physiotherapist should be guided by his patient's wellbeing, taking into account recommendations of current medical knowledge and professional ethical principles. At this point it is worth noting that the professional independence of physiotherapists has not been particularly prominently displayed among the principles of professional ethics of physiotherapists [12] cf. This issue raises some controversy in the field. It is indicated that in the wake of developed privileges, there is also increased legal responsibility [Cf. 13]. Additionally, in order to ensure an appropriate quality of health care services provided, the Legislator introduced in Article 4, paragraph 4 of the APP some limitations as to their independent provision by physiotherapists. Pursuant to this provision, the right to independently perform health care services listed in the Act is available to the full extent only to physiotherapists who have obtained a Master's degree in the manner specified in Article 13, paragraph 3, point 1 of the APP (i.e. if after 1 October 2017 they started a uniform 5 -year higher education in the field of physiotherapy, covering a specific number of ECTS points, and completed a sixmonth professional practice, obtained a Master's degree and passed the State Physiotherapy Exam). Physiotherapists who have obtained a Master's degree in a different educational path must document a three-year experience. On the other hand, for individuals with a Bachelor's degree or the title of a Physiotherapy Technician and with 6 years of experience as physiotherapist, the possibility to independently provide health care services has been limited (Article 4, paragraph 4 of the APP). In addition, individuals with a Bachelor's degree or the title of a Physiotherapy Technician are allowed to exercise physical therapy and kinesitherapy, as well as to order medical devices and give opinions and judgments about the functional status of people undergoing physiotherapy and the course of such process (Article 4, paragraph 5 of the APP). In the end, physiotherapists as representatives of a medical profession are obliged to inform the patient about his rights as well as to provide information to the patient to the extent necessary for the health services they provide (Article 9 of the APP).

Physiotherapists practise a medical profession by acting on the account of another entity, under a contract of employment or a civil law contract. They can also provide health care services by running their own business. They act then as entrepreneurs [14] and are entered in the register of regulated activities conducted for medical entities [Article 16 of the ATA]. Then they cannot refuse to provide a health care service to a person who needs immediate provision of such a service due to a threat to life or health [Article 15 of the ATA].

The legal conditions for exercising this profession in Poland result from its unique social character, which directly determined its recognition as a profession of public trust, within the 
meaning of Article 17, paragraph 1 of the Constitution, according to which: "By means of a statute, self-governments may be created within a profession in which the public repose confidence, and such self-governments shall concern themselves with the proper practice of such professions in accordance with, and for the purpose of protecting, the public interest." Thus, it is assumed that the professions recognized by the Legislator as professions of public trust are, in fact, all those professions for which the requirement to create a professional self-government was introduced [15]. The legal basis for the appointment of the professional self-government of physiotherapists may be found in Article 3 of the APP, where it was indicated that this self-government represents people exercising the profession of physiotherapist and supervises the proper practise of this profession within the public interest and for its protection, and membership is compulsory for physiotherapists. The self-government is independent in the performance of its tasks and is subject only to the provisions of the Act. The organizational unit of the self-government with legal personality is the National Chamber of Physiotherapists (NCP) based in Warsaw The NCP exercises supervision in the field of occupational responsibility as the members of the self-government are subject to professional liability for violation of the rules of professional ethics or regulations regarding the pursuit of the profession (Article 85 of the APP).

Recognition of a given profession as a profession of public trust is associated with the legal doctrine with specific properties: it is a profession that consists in handling personal human needs, which entails collecting information about personal life, and which is organized in a way that justifies the social conviction that the use of this information by providers of services is in an individual's best interest; the practice of a profession of public trust is also determined by standards of professional ethics, the specific wording of the oath, the tradition of the professional corporation or the special nature of higher education and the specialization obtained; the attribute of a profession of "public trust" lies in watching over managing matters or protecting the values (goods) that are essential and (most often) of personal importance for people using services in the sphere of public trust as well as in undertaking important in the public dimension - professional activities that require professional preparation, experience, discretion, tact and personal culture [16]. This trust consists of many factors, among which the following are at the forefront: the belief in the good will of the person practising a given profession, the right motivations, professional diligence and faith in compliance with the values relevant to the profile of the profession. With respect to practising professions of public trust, the essential values include full and integral respect for the law, in particular compliance with constitutional values (in their hierarchy) and procedural directives [16]. Among other features, the obligation to keep confidential information related to the patient, obtained in connection with the pursuit of the profession, is characteristic for performing physiotherapists' profession.

In the light of adopted regulations, the profession of physiotherapist can be considered a liberal profession. It is true that there is no legal definition of a liberal profession. However, in principle, the doctrine of law is consistent as to the personal and independent practising of a liberal profession, the intellectual nature of professional activities undertaken as part of this activity and high qualifications of these professionals. K. Wojtczak indicates the following traits defining a liberal profes- sion: "personal and independent performance of an internally coherent set of intellectual activities requiring high qualifications (knowledge and practice), systematic performance in exchange for a fee selflessly established to provide benefits and services to clients, and protection of other values of general interest in accordance with applicable legal norms, ethical and deontological principles" [17].

The important features of practising a liberal profession are also: the mission to practice, complying with deontological rules, ensuring professional secrecy and trust and bearing a special responsibility due to the manner in which the order is executed [18]. Above all, attention is paid to the personal and independent practising of a liberal profession. Physiotherapists undoubtedly meet this criterion. Health care services are provided personally, only a natural person who has the appropriate authorization can perform them. Services provided by physiotherapists also have an intellectual value. To perform them one needs not only special knowledge, but also the ability to skilfully apply it in practice. The requirement of high qualifications has already been confirmed earlier. On the other hand, the regularity of exercising this profession manifests itself in the fact that in the case of a significant break in practising of this profession, i.e. a break of more than 5 years in the last 6 years, in order to be able to continue working they must complete a special training (Article 11 of the APP) [19]. The profession of physiotherapist is also a regulated profession within the meaning of Directive 2005/36/EC [20], according to which, a regulated profession is a professional activity whose conditions of taking or practising are regulated directly or indirectly by statutory laws, regulations or administrative provisions that impose the obligation to have special professional qualifications and resulting from the legislation of a given country. It is also a regulated profession under the Act of 18 March 2008 on the rules governing recognition of professional qualifications acquired in EU Member States [21]. Pursuant to this law, a regulated profession is a set of professional activities the performance of which depends on having formal qualifications, specified in the regulatory provisions, that are necessary to perform these professional activities, and, if it is required, on fulfilling other conditions established in these regulations. These criteria are met by the analyzed regulation regarding a selected group of medical professions. Physiotherapists, as a professional group, were listed in the Regulation of the Prime Minister on the list of regulated professions and regulated activities in the performance of which the service provider has a direct impact on public health or safety, for which proceedings for recognition of qualifications can be initiated [22] entered as item no. 8. Thus, people originating in particular from EU countries - after completing the procedure for the recognition of qualifications by the competent authority, which checks: the level of education and qualifications giving the right to practise a given regulated profession in the country in which they were obtained - they can practise this profession in Poland. And accordingly, people who have received their professional license in Poland can apply for practice in the EU.

\section{CONCLUSIONS}

The presented legal framework determining the occupational status of physiotherapists, referring to the state before the entry into force of the provisions of the analyzed Act, indicates significant progress in the field of regulatory activities. 
It has been shown above that the profession of physiotherapist meets the expectations defined both by relevant normative acts and by the legal doctrine in relation to medical professions, liberal professions or professions of public trust - as a category determining the highest expected level of quality of services. However, some areas should be indicated in which statutory regulation was neglected. These deficiencies may lead to negative consequences, both for physiotherapists and patients.

The first area in which the lack of regulations may cause the lack of safety on the part of patients is failing to introduce a mandatory requirement of public liability insurance for the entire professional group. This obligation rests only on those physiotherapists who practise their profession in the form of economic activity as health care entities [Article 252 of the 5 ATA], but not on people who provide health care services to patients in medical facilities with whom they co-operate on the basis of civil law contracts.

Another gap that has not been subjected to regulation is not fulfilling the obligation to continually improve their qualifications. This obligation was not introduced as a statutory obligation, and thus no standards were set for this education. This is all the more important because physiotherapists have the obligation to provide services in accordance with the current state of medical knowledge. Obtaining this knowledge, without adequate sanctioning, as in the case of other medical professions, should be considered as an important oversight which should be eliminated as soon as possible.

\section{REFERENCES}

1. M. Starczyńska J, Karwacińska B, Stepanek-Finda W, et al. Historyczne podstawy fizjoterapii. Studia Med. 2011;21:71-7.

2. Act of 25 September 2015 on Physiotherapist's Profession (Dz.U.2015.1994), hereinafter referred to as the Act on Physiotherapist's Profession or the APP.

3. Justification of the draft Act of the Sejm of the Republic of Poland for the seventh term of office. Print No.: 3001, draft of the Act on the physiotherapist's profession and changes of other Acts; http://www.sejm.gov.pl/ Sejm7.nsf/PrzebiegProc.xsp?nr=3001;

4. The Act of 15 April 2011 on Therapeutic Activity, Dz.U. 2015, item 618, as amended, hereinafter referred to as ATA;

5. The Act of 6 November 2008 on Patients' Rights and Patient Ombudsman, consolidated text - Dz. U. 2017, item 1318 with amendments - hereinafter referred to as APR.

6. The Constitution of the Republic of Poland OF 2nd APRIL, 1997 (Dziennik Ustaw No. 78, item 483).

7. The Act of 27 August 2004 on Health Care Services Financed from Public Funds ( consolidated text Dz. U. 2017, item 1938, as amended - hereinafter called AHCS)

8. Karkowska D. Zakres przedmiotowy pojęcia „zawód medyczny”. In: Zawody medyczne. Warszawa; 2012. Lex el. 151446.

9. The Act of 12 May 2011 on Reimbursement of Medicines, Food Products for Particular Nutritional Uses and Medical Devices (Dz.U. 2017, item 1844, as amended - hereinafter called Reim)

10. Resolution of the Supreme Court of 31 August 1994. IKZP 20/94, OSP 1995, vol. 2, item 40.

11. The Penal Code of 6 June 1997 (Dz.U. 2017, item 2204 and Dz.U. 2018, item 20 and 305 as amended - hereinafter called PK)

12. Resolution no 20/I KZF/2016 of I Krajowego Zjazdu Fizjoterapeutów (I National Convention of Physiotherapists) of 29 December 2016 on „Zasady etyki zawodowej fizjoterapeutów” ("Rules of Professional Ethics of Physiotherapists"); access: https://kif.info.pl/wp-content/ uploads/2017/01/20-I-KZF-2016-zal.pdf; 25.06.2018].

13. Białoszewski $D$, Wroński $Z$. Nowa pozycja fizjoterapeuty wśród zawodów medycznych w świetle nowych zapisów prawnych i nowego systemu kształcenia zawodowego. In: D. Białoszewski, Z Wroński (eds). Fizjoterapia w Polsce Warszawa; 2017. p. 7.

14. The Act of 6 March 2018 - Law on Entrepreneurs (Dz.U. 2018, item 646).

15. Kocowski T. Zawód zaufania publicznego w gospodarce rynkowejrzeczywistość czy przeżytek. In: U. Kalina-Prasznic (ed). Stare dogmaty - nowe wyzwania w prawie i ekonomii. Wolters Kluwer Business; 2003. p 135-53.

16. Komentarz do Art 17 Konstytucji RP. In: Konstytucja RP. Komentarz Safjan, Bosek (eds), 2016, Edition 1/Szydło, p. 434

17. Wojtczak K. Zawód i jego prawna reglamentacja. Poznań; 1999. p. 84

18. Krasnowolski. Zawody zaufania publicznego, zawody regulowane oraz wolne zawody. Geneza, funkcjonowanie i aktualne problemy. Warszawa; 2013. p. 3.

19. Kłusek P. Fizjoterapeuta jako wolny zawód i zawód zaufania publicznego. ROZPRAWY NAUKOWE Akademii Wychowania Fizycznego we Wrocławiu; 2016. p.53, 44-56.

20. Directive 2005/36/EC of the European Parliament and of the Council of 7 September 2005 on the recognition of professional qualifications (Official Journal L 255, p. 22),

21. The Act of 18 March 2008 on the rules for the recognition of professional qualifications acquired in the Member States of the European Union (Dz.U. No. 63, item 394)

22. The Regulation of the Prime Minister of 27 February 2017 on the list of regulated professions and regulated activities in the performance of which the service provider has a direct impact on public health or safety, for which proceedings for recognition of qualifications can be initiated (Dz.U.2017.468).

\section{Corresponding author}

Dr Katarzyna Mełgieś

Department of Administrative Law, Faculty of Law, Canon Law and Administration

John Paul II Catholic University of Lublin, Poland

E-mail:katarzyna.melgies@gmail.com 